\title{
OPTIMALISASI HASIL BELAJAR MELALUI KLASIFIKASI RAGAM GAYA BELAJAR SISWA
}

\author{
Abd. Ghofur* \\ STKIP PGRI Lamongan \\ ghofurkita@yahoo.com
}

\begin{abstract}
ABSTRAK
Setiap anak mempunyai cara tersendiri untuk bisa memahami dan mengakses informasi. Keberagaman gaya belajar tersebut membuat pembelajaran terkesan hanya dinikmati para siswa yang mampu mengakses informasi yang disampaikan oleh gurunya. Bagi siswa yang kesulitan menerima informasi tentu akan membuat aktivitas belajar sendiri, misalnya asyik berbicara dengan temannya, melamun, bahkan tertidur saat pelajaran masih berlangsung. Beberapa ahli membagi modalitas belajar menjadi tiga dimensi, yakni gaya belajar visual (belajar dengan cara melihat), Auditorial (belajar dengan cara mendengar), dan kinestetik (belajar dengan cara bergerak, bekerja, dan menyentuh). Ketiganya tentu memiliki karakteristik berbeda yang tentunya juga berbeda strategi yang diterapkan dalam pembelajaran. Kalau guru tidak memberikan porsi yang sama untuk setiap modalitas belajar siswa dalam strategi dan pemilihan metode pembelajaran, maka hasil belajarnya tentu berbeda. Guru perlu mengklasifikasikan gaya belajar yang dimiliki oleh siswa, kemudian menentukan strategi dan metode yang sesuai dengan gaya belajar siswa masing-masing. Kalau hal ini dilakukan, proses pembelajaran tentu akan berjalan optimal dan memakasimalkan hasil belajar siswa.
\end{abstract}

Kata Kunci: Hasil Belajar, Klasifikasi Gaya Belajar

\section{Pendahuluan}

Suatu pemahaman dapat dikatan berbeda karena dipengaruhi oleh cara penyampaian informasi dari pendidik dan gaya belajar pada tiap individu. Setiap orang memiliki gaya belajar yang berbeda dan bisa belajar dengan lebih baik dengan cara yang berbeda-beda. Setiap anak diilhami cara bagaimana mereka memahami sesuatu dengan mudah. Setidaknya hal ini yang harus menjadi acuan para guru untuk memilih metode pembelajaran yang sesuai dengan karakteristik mereka. Sehingga output yang diharapkan oleh guru bisa dicapai sesuai dengan harapan, dan siswapun bisa merasakan indahnya belajar. Mengenai hal ini, White (2010) menjelaskan bahwa guru selalu berasumsi bahwa semua siswa selalu siap untuk mengikuti pelajaran. Padahal sering kali terlihat di dalam kelas ada siswa yang mengantuk, melamun, bermain sendiri, ada juga yang memperhatikan dengan seksama, menulis setiap ucapan guru, dan beragam tindakan lainnya. Hal itu menunjukkan bahwa setiap siswa memiliki motivasi yang berbeda dalam belajar, yang tentunya akan berpengaruh terhadap proses pembelajaran.

Di dalam artikelnya White (2010) juga menguraikan bahwa seorang guru harus memahami modalitas belajar siswanya. Setiap anak memiliki tiga modalitas belajar, yakni visual, auditorial dan kinestetik. Sebab, kebanyakan peserta didik menyaring, mengolah, dan berkomunikasi dalam pembelajaran menggunakan modalitas tersebut. Modalitas Visual mengakses citra visual yang diciptakan atau diingat. Misalnya, warna, hubungan spasial, gambar, dan lainnya. Sedangkan Modalitas Auditorial mengakses segala macam bunyi dan kata yang diciptakan atau diingat, misalnya musik, nada, irama, sajak, dialog dan sebagainya. Kemudian modalitas kinestetik mengakses hal yang diperbuat atau mengingat dengan gerakan dan emosi, misalnya gerakan koordinasi, respon emosional terhadap irama dan kenyamanan fisik.

Gaya belajar yang dimiliki oleh siswa menjadi karakteristik yang bersangkutan untuk mendapatkan informasi. Siswa tentu akan dengan mudah mendapatkan informasi pelajaran dengan metode ceramah jika siswa tersebut bergaya belajar auditorial. Sebaliknya, metode ceramah tentu kurang disukai bagi mereka yang gaya belajarnya visual (belajar melalui melihat) ataupun yang gaya belajar siswanya kinestetik (belajar dengan bergerak). 
Oleh karena itu, Ahmed (2012) menegaskan dalam artikelnya bahwa gaya belajar mengacu pada karakteristik individu dan cara pilihan dalam pengumpulan, menafsirkan, mengatur dan berpikir tentang informasi. Beberapa peserta didik lebih suka belajar dengan cara bentuk visual dari informasi yang disajikan, seperti gambar, diagram, dan skema. Siswa lain lebih memilih untuk belajar dari bentuk-bentuk verbal, seperti penjelasan lisan dan tulisan, beberapa peserta didik cenderung untuk fokus pada fakta dan data. Ada juga yang lain lebih nyaman dengan teori-teori dan model matematika, beberapa siswa lain mendukung pembelajaran aktif dan interaktif; lainnya lebih memilih untuk belajar lebih tertutup dan individual. Beberapa peneliti telah menemukan bahwa pengaruh media dan lingkungan belajar yang sama menunjukan beberapa siswa dapat belajar dengan mudah dan mencapai sukses sementara yang lain merasa sulit dan putus asa. Mereka percaya bahwa hal ini mungkin disebabkan fakta bahwa setiap individu memiliki cara yang lebih disukai dalam belajar.

Keberadaan Gaya belajar yang dimiliki setiap individu sering tidak dirasakan atau digunakan secara sadar. Padahal gaya belajar merupakan dasar untuk asupan dan pemahaman informasi yang disampaikan oleh guru kepada siswanya. Siswa dapat mengidentifikasi gaya belajar yang mereka pilih dan mengembangkan gaya belajar dengan memeriksa dan berlatih berbagai strategi pembelajaran yang disajikan oleh guru.

\section{Karekteristik Gaya Belajar dan Pemilihan Strategi Pembelajaran}

Pada dasarnya setiap individu menggunakan semua indera dalam menyerap informasi. Menanggapi hal tersebut, Degeng (2002) menguraikan bahwa gaya belajar, rentangan perhatian, ingatan, tahap perkembangan dan kecerdasan pebelajar sangat bervariasi. Secara umum gambaran tentang proses dan gaya belajar mencakup dua aspek, yaitu (1) bagaimana menyerap informasi dengan mudah (modalitas), dan (2) bagaimana cara mengatur dan mengelola informasi tersebut (dominasi otak).

Cara siswa dalam mengakses informasi menjadi pijakan para pendidik untuk menentukan bagaimana strategi yang dipakai dalam pembelajaran. Karena banyak ahli meyakini bahwa setiap individu tidak hanya belajar dengan kecepatan yang berbeda tetapi juga memperoleh informasi dengan cara yang berbeda. Cara memproses informasi yang diperoleh dikenal dengan istilah gaya belajar. Menanggapi hal tersebut, DePorter dan Hernacki (2002) menguraikan bahwa gaya belajar adalah kombinasi dari menyerap, mengatur, dan mengolah informasi. Berdasarkan modalitas yang digunakan individu dalam memproses informasi (perceptual modality) terdapat tiga jenis gaya belajar. Ketiga gaya belajar tersebut adalah gaya belajar visual (belajar dengan cara melihat), Auditorial (belajar dengan cara mendengar), dan kinestetik (belajar dengan cara bergerak, bekerja, dan menyentuh).

Untuk mengetahui secara detail penjelasan masing-masing tiga gaya belajar tersebut dan penggunaan strategi pembelajaran yang tepat, diuraikan sebagai berikut:

\section{a. Visual Learner (Gaya Belajar Visual)}

Ada beberapa karakteristik yang dimiliki oleh siswa yang memiliki gaya belajar visual. Sebagaiamana dijelaskan DePorter dan Hernacki (2002) bahwa modalitas belajar ini mengakses citra visual yang diciptakan maupun diingat. Bisa berupa warna, hubungan ruang, potret mental, dan gambar menonjol.

Secara detail, siswa yang memiliki gaya belajar visual memiliki cirri-ciri sebagai berikut:

1) Berbicara dengan cepat

2) Mementingkan penampilan, baik dalam hal pakaian maupun presentasi

3) Mengingat apa yang dilihat, daripada yang didengar

4) Biasanya tidak terganggu oleh keributan

5) Mempunyai masalah untuk mengingat instruksi verbal kecuali jika ditulis, dan seringkali minta bantuan orang untuk mengulanginya

6) Pembaca cepat dan tekun

7) Lebih suka membaca daripada dibacakan

8) Lebih suka melakukan demonstrasi daripada berpidato

9) Lebih suka seni daripada musik

10) Seringkali mengetahui apa yang harus dikatakan, tetapi tidak pandai memilih kata-kata

11) Kadang-kadang kehilangan konsentrasi ketika mereka ingin memperhatikan. 
Untuk mempermudah dan mengoptimalkan proses belajar siswa yang memiliki gaya belajar visual, Suparman (2010) merekomendasikan strategi yang harus dilakukan oleh para pendidik, yakni sebagai berikut:

1) Gunakan materi visual seperti tulisan, gambar-gambar, diagram dan peta

2) Gunakan warna untuk menandai hal-hal penting

3) Ajak anak untuk membaca buku-buku berilustrasi

4) Gunakan multimedia visual seperti computer dan video

5) Arahkan anak untuk mencoba mengilustrasikan ide-idenya ke dalam bentuk tulisan atau gambar.

Selain strategi yang tersebut diatas, Parfin (2009) juga menganjurkan strategi pengajaran lain bagi siswa yang memiliki gaya belajar visual. Starateginya adalah dengan menggambar, mencatat, menonton video, pengimajinasian terpimpin, peragaan, pengajaran komputer, membuat kode berwarna, peta pikiran, garis waktu, flow chart, daya ingat melalui penglihatan, menggunakan petunjuk tertulis, menggunakan gambar, diagram, peta dan denah, flash card, menekankan teks dengan warnawarni, pembelajaran independen, peragaan visual transparansi.

\section{b. Auditory Learner (gaya belajar auditorial)}

Siswa yang memiliki gaya belajar auditorial menggambarkan preferensi terhadap informasi yang didengar atau diucapkan. Menurut DePorter dan Hernacki (2002) gaya belajar auditorial mengakses segala jenis bunyi dan kata yang diciptakan maupun diingat. Musik, nada, irama, rima. Dialog internal, dan suara menonjol disini. Modalitas ini memanfaatkan kemampuan "pendengarannya" sebagai gaya belajar yang disukainya. Beberapa ciri auditory learner antara lain: 1) berbicara pada diri sendiri saat bekerja, 2) mudah terganggu oleh keributan, 3) menggerakkan bibir dan mengucapkan tulisan di buku saat membaca, 4) merasa kesulitan untuk menulis, namun hebat dalam berbicara, 5) lebih suka gurauan lisan dari pada komik, 6) berbicara dalam irama terpola, 7) belajar dengan mendengarkan dan mengingat apa yang didiskusikan dari pada yang dilihat, 8) suka menjelaskan sesuatu panjang lebar, 9) dapat menirukan warna, irama, dan nada suara lain.

Berdasarkan karakteristik yang dimiliki siswa yang memiliki gaya belajar auditorial, Suparman (2010) merekomendasikan beberapa starategi yang bisa dilakukan oleh guru dalam proses pembelajaran, diantara:

1) Ajak anak untuk ikut berpartisipasi dalam setiap diskusi yang dilakukan secara verbal

2) Dorong anak untuk membaca materi pelajaran dengan keras

3) Gunakan musik sebagai background untuk mengajarkan anak

4) Arahkan anak agar merekam materi pelajarannya kedalam kaset dan minta dia untuk senantiasa mendengarkannya sebelum tidur

5) Sebagai orang tua, baiknya bantu anak ketika belajar dengan membacakan materi pelajarannya atau mengajaknya berdiskusi mengenai materi pelajarannya.

Selain itu, DePorter dan Hernacki (2000) juga menguraikan adanya strategi lain yang bisa digunakan dalam mempermudah pembelajaran anak auditorial yakni dengan mendengarkan kuliah, contoh, dan cerita serta mengulang informasi adalah cara-cara utama belajar mereka. Dapat pula membuat fakta panjang yang mudah diingat oleh siswa auditorial dengan mengubahnya menjadi lagu, dengan melodi yang sudah dikenal baik.

\section{c. Kinesthetic Learner (Gaya belajar kinestetik)}

Siswa yang memiliki gaya belajar kinestetik cenderung belajar malalui gerak, emosi dan sentuhan. Hal ini sebagaimana yang disampaikan DePorter dan Hernacki (2002) bahwa siswa auditorial mengakses segala jenis gerak dan emosi yang diciptakan maupun yang diingat. Gerakan, koordinasi, irama, tanggapan emosional, dan kenyamanan fisik menonjol disini. Kinesthetic learner adalah seorang anak yang memanfaatkan "fisiknya" sebagai alat belajar yang optimal. Beberapa karakteristiknya adalah sebagai berikut:

1) Berbicara dengan perlahan 
2) Menyentuh orang untuk mendapatkan perhatian mereka

3) Belajar melalui memanipulasi dan praktek

4) Menghafal dengan cara berjalan dan melihat

5) Menggunakan jari sebagai penunjuk ketika membaca

6) Tidak dapat mengingat geografi, kecuali jika mereka memang telah pernah berada ditempat itu

7) Menyukai buku-buku dan mereka mencerminkan aksi dengan gerakan tubuh saat membaca

8) Menyukai permainan yang menyibukkan

9) Tidak terlalu mudah terganggu dengan situasi keributan.

Berdasarkan beberapa karakteristik tersebut diatas, Suparman (2010) merekomendasikan beberapa strategi untuk mempermudah proses belajar anak yang memiliki gaya belajar kinestetik, yakni:

1) Jangan paksakan anak untuk belajar sampai berjam-jam

2) Arahkan anak untuk belajar sambil mengeksplorasi lingkungannya, misalnya: belajar menanam dengan cara langsung mempraktekannya

3) Izinkan anak untuk mengunyah sesuatu, misalnya permen karet pada saat belajar

4) Gunakan warna terang untuk menandai hal-hal penting dalam bacaan

5) Izinkan anak untuk belajar sambil mendengarkan musik, sebab biasanya ketika mereka belajar dengan musik anggota tubuhnya (misalnya kepala atau kakinya) ikut bergerak mengikuti irama musik.

\section{Mengidentifikasi Gaya Belajar Siswa}

Untuk mengetahui gaya belajar yang dimiliki oleh masing-masing siswa, diawal pembelajaran guru memberikan kuesioner yang diisi siswa untuk mengidentifikasinya. Instrumen gaya belajar digunakan untuk menilai apakah siswa memiliki kecenderungan gaya belajar visual, auditorial atau kinestetik. Instrumen tersebut masing-masing gaya belajar terdiri dari 12 butir pertanyaan. Masing-masing pertanyaan diberi tiga pilihan jawaban untuk dipilih salah satu, yaitu: sering, kadang-kadang, dan jarang.

Tabel 1. Kuesioner untuk mengetahui gaya belajar visual

\begin{tabular}{clll}
\hline No & \multicolumn{1}{c}{ Pertanyaan } & S & J \\
\hline 1 & Apakah Anda rapi dan teratur & \\
\hline 2 & Apakah Anda berbicara dengan cepat & \\
\hline 3 & Apakah Anda perencana dan pengatur jangka panjang yang baik & \\
\hline 4 & $\begin{array}{l}\text { Apakah Anda pengeja yang baik dan dapatkah anda melihat kata-kata dalam } \\
\text { pikiran anda }\end{array}$ & \\
\hline 5 & Apakah anda lebih ingat apa yang dilihat daripada yag didengar \\
\hline 6 & Apakah anda menghafal dengan asosiasi visual? & \\
\hline 7 & $\begin{array}{l}\text { Apakah anda sulit mengingat perintah lisan kecuali jika dituliskan, dan apakah } \\
\text { anda sering meminta orang mengulang ucapannya? }\end{array}$ \\
\hline 8 & Apakah anda lebih suka membaca daripada dibacakan? \\
\hline 9 & Apakah anda suka mencoret-coret selama menelpon/menghadiri rapat? \\
\hline 10 & Apakah anda lebih suka demonstrasi daripada berpidato? \\
\hline 11 & Apakah Anda lebih menyukai seni daripada music? \\
\hline 12 & $\begin{array}{l}\text { Apakah Anda tahu apa yang harus dikatakan, tetapi tidak berfikir kata yang } \\
\text { tepat? }\end{array}$ & \\
\hline & S: Sering, K: Kadang-kadang, J: Jarang
\end{tabular}

Tabel 2. Kuesioner untuk mengetahui gaya belajar Auditorial

\begin{tabular}{ccccc}
\hline No & Pertanyaan & S & K & J \\
\hline 1 & Apakah anda berbicara kepada diri sendiri saat bekerja? & & \\
\hline
\end{tabular}

The 6Th International Conference on Educational Technology of Adi Buana, $9^{\text {th }}$ May 2015 


\begin{tabular}{ll}
\hline 2 & Apakah anda mudah terganggu oleh keributan? \\
\hline 3 & Apakah anda menggerakka bibir/melafalkan kata saat membaca? \\
\hline 4 & Apakah anda suka membaca keras-keras dan mendengarkan? \\
\hline 5 & Dapatkah anda mengulang dan menirukan nada, perubahan, dan warna suara? \\
\hline 6 & Apakah anda merasa menulis itu sulit tetapi pandai bercerita? \\
\hline 7 & Apakah anda berbicara dengan pola berirama? \\
\hline 8 & Apakah anda adalah pembicara yang fasih? \\
\hline 9 & Apakah anda lebih menyukai musik daripada seni? \\
\hline 10 & $\begin{array}{l}\text { Apakah anda belajar melalui mendengar dan mengingat apa yang didiskusikan } \\
\text { daripada yang dilihat? }\end{array}$ \\
\hline \multirow{2}{1}{11} & $\begin{array}{l}\text { Apakah anda banyak berbicara, suka berdiskusi, dan menjelaskan panjang } \\
\text { lebar? }\end{array}$ \\
\hline 12 & Apakah anda lebih baik mengeja keras-keras daripada menulisnya? \\
\hline
\end{tabular}

(Adaptasi Deporter, 2002)

Tabel 3. Kuesioner untuk mengetahui gaya belajar Kinestetik



S: Sering, K: Kadang-kadang, J: Jarang $\quad$ (Adaptasi Deporter, 2002)

Pada ketiga instrumen tersebut masing-masing siswa akan mengisi dengan memberikan tanda centang $(\sqrt{ })$ pada kolom jawaban, yakni S untuk sering, $\mathrm{K}$ untuk kadang-kadang dan $\mathrm{J}$ untuk jarang. Banyaknya pertanyaan yang dicentang untuk masing-masing kuesioner diberikan nilai, yakni dengan rumus sebagi berikut:

Nilai Gaya Belajar $=\sum \mathrm{S} \times 2+\sum \mathrm{K} \times 1+\sum \mathrm{J}$ x 0

Skor yang akan diperoleh dari masing-masing instrumen yang mewakili gaya belajar tersebut kemudian dibandingkan. Skor instrumen yang paling tinggi menunjukan kecenderungan gaya belajar yang dimiliki oleh siswa tersebut. Dengan instrumen ini siswa dapat dikelompokkan dalam tiga ketegori, yaitu siswa yang memiliki gaya belajar visual, auditorial dan kinestetik.

\section{Pengaruh Gaya Belajar terhadap Hasil Belajar}

Memahami gaya belajar yang dimiliki oleh setiap siswa merupakan cara terbaik untuk memaksimalkan proses pembelajaran di kelas. Setelah siswa menemukan gaya belajar dan guru mengetahui strategi terbaik untuk 
membantu dalam belajarnya, dampaknya dapat dilihat kemampuan siswa memahami sesuatu akan berkembang dengan pesat di dalam kelas, bahkan di mata pelajaran yang sebelumnya dianggap susah dan rumit.

Beberapa penelitian menunjukan bahwa gaya belajar yang dimiliki oleh siswa berpengaruh terhadap hasil belajarnya. Misalnya Nurlela (2007) menyimpulkan bahwa ada perbedaan hasil belajar bahasa Indonesia antara siswa yang bergaya belajar visual dan siswa yang bergaya belajar auditorial. Hasil belajar siswa yang bergaya belajar visual lebih tinggi dari pada siswa yang bergaya belajar auditorial.

Selain itu, Gilakjani (2012) juga pernah melakukan penelitian untuk mengetahui gaya belajar siswa dan dampaknya dalam pembelajaran Bahasa Inggris di Iran. Hasil di Kelas tempat penelitian tersebut menunjukan bahwa gaya belajar visual yang paling mendominasi, dilanjutkan auditori dan kinestetik. Dia juga mengungkapkan bahwa siswa belajar terbaik dengan melihat nilai dan pentingnya informasi yang disajikan dalam kelas. Jika siswa tidak tertarik pada materi yang disampaikan, mereka tidak akan mempelajarinya. Klasifikasi gaya belajar siswa akan memungkinkan siswa untuk menentukan kekuatan dan kelemahan pribadinya sendiri dan belajar dari hal tersebut. Guru dapat menggunakan gaya belajar siswa di kelas dengan mengidentifikasi cara belajar masing-masing siswa, kemudian menyesuaikan gaya mengajar dengan gaya belajar untuk pemberian tugas yang sulit atau mudah, dan juga penyesuaian strategi pembelajaran dengan beragam gaya belajar yang dimiliki siswa.

Seringkali anak terlihat bodoh dan tidak bisa mengikuti alur belajar yang dibuat oleh guru karena kurang cocok dengan cara dia belajar. Akhirnya anak asyik bermain sendiri, mengganggu teman yang lain, atau aktifitas lain yang ia lampiaskan karena gurunya tidak memberikan ruang bagaimana cara mereka belajar. Mengetahui gaya belajar yang dimiliki siswa ini penting bagi guru karena berkaitan dengan bagaimana dia mengolah pembelajaran yang sesuai dengan karakteristik belajar siswanya. Pada dasarnya pembelajaran akan berhasil jika antara guru dan siswa saling mengetahui karakteristik masing-masing, sehingga pembelajaran bisa berjalan sesuai targetnya.

Gaya belajar adalah variasi cara yang dimiliki seseorang untuk mengakumulasi serta mengasimilasi informasi. Pada dasarnya gaya belajar adalah metode terbaik yang memungkinkan dalam mengumpulkan dan menggunakan pengetahuan secara spesifik. Kebanyakan ahli setuju bahwa ada tiga macam dasar gaya belajar. Setiap individu memungkinkan untuk memiliki satu macam gaya belajar atau dapat memiliki kombinasi dari gaya belajar yang berbeda. Di sebagian besar kasus, karakteristik gaya belajar bahkan dapat diamati pada anak yang memiliki usia relative muda.

Hasil temuan Lambas (2008) dan Rambe (2011) mengemukakan bahwa gaya belajar dapat mempengaruhi hasil belajar siswa. Jika diberikan strategi yang sesuai dengan gaya belajarnya siswa dapat berkembang dengan lebih baik. Gaya belajar dapat meningkatkan daya serap terhadap materi pelajaran yang disampaikan guru. Keberhasilan belajar ditentukan oleh kemampuan untuk mengembangkan cara memproses informasi yang paling efektif sesuai dengan gaya belajar.

Setelah siswa mengenali gaya belajar yang dimilikinya, maka siswa dapat menerapkan cara belajar yang baik dan sesuai dengan gaya belajarnya, sehingga siswa dapat memaksimalkan prestasi belajar akademik maupun non akademik. Didalam proses belajar tidak ada cara belajar yang dianggap benar atau salah karena setiap orang mempunyai gaya belajar yang berbeda-beda dan memberikan keuntungan serta kekurangan masingmasing. Ketika siswa mampu memahami gaya belajarnya maka proses belajar siswa akan lebih efisien dan efektif.

\section{Penutup}

Setiap anak terlahir dalam kondisi yang bersih dan suci, lingkungan dan perilaku orang di sekelilingnya yang mempengaruhi perkembangan anak. Demikian juga, tak ada siswa yang terlahir dalam kondisi bodoh, tinggal bagaimana lingkungan dan orang di sekelilingnya (guru dan orangtua) memberikan informasi dengan bentuk dan strategi yang sesuai dengan modalitas siswanya. Siswa sering mengalami kesulitan dalam belajar, hal ini disebabkan karena akses informasi yang mereka dapatkan tidak sesuai dengan gaya belajar yang mereka miliki. Dampaknya tentu sangat dirasakan oleh para guru, diantaranya siswa lebih memilih melamun, asyik bicara sendiri dengan temannya, bahkan ada yang sampai tertidur di kelas saat sang guru masih sibuk menjelaskan pelajaran.

The 6 Th International Conference on Educational Technology of Adi Buana, $9^{\text {th }}$ May 2015 
Cassidy (2004) menilai bahwa setiap individu tidak hanya belajar dengan kecepatan yang berbeda tetapi juga memperoleh informasi dengan cara yang berbeda. Cara memproses informasi yang diperoleh dikenal dengan istilah gaya belajar. Gaya belajar menunjukan cara seorang individu dalam memproses informasi dengan tujuan mempelajari dan menerapkannya. Gaya belajar adalah pola-pola perilaku yang konsisten untuk mengkonstruksi pengetahuan yang menyatu dengan pengalaman konkret atau kehidupan nyata siswa.

Cara mengakses informasi antara siswa yang satu dengan yang lainnya berbeda, hal ini tentu akan menjadi masalah jika guru salah dalam menentukan strategi dan metode pembelajaran. Misalnya saja, ketika guru menyampaikan materi pelajaran dengan metode ceramah, tentu siswa yang memiliki gaya belajar auditorial akan senang mendengarnya, namun siswa yang bergaya belajar visual dan kinestetik tentu akan memilih aktivitas lainnya di kelas. Berkaitan dengan hal tersebut, setiap guru harus betul-betul memahami cara memperoleh informasi dalam belajar peserta didiknya. Seorang guru harus mampu meramu pembelajaran dengan melibatkan semua siswa yang memiliki latar belakang modalitas belajar yang berbeda.

Guru bisa mengoptimalkan proses pembelajaran dengan cara mengklasifikasikan ragam gaya belajar yang dimiliki siswanya yang ada dalam satu kelas. Hal ini perlu dilakukan untuk mengetahui strategi yang sesuai dengan gaya belajar yang dimiliki masing-masing siswa. Pengelompokan ini akan mempermudah siswa mengakses informasi yang sesuai dengan cara dia belajar. Hasilnya tentu pembelajaran akan lebih bergairah dan menyenangkan bagi siswa, sebab guru mengetahui apa yang siswa mau. Guru pun akan terbantu, sebab proses pembelajaran akan berjalan dinamis, efektif dan optimal.

\section{Daftar Pustaka}

Ahmed, Omnia Nabih. 2012. The Effect of Different Learning Styles on Developing Writing Skills of EFl Saudi Learners. British Journal of Arts and Social Sciences. Volume 5 (2): Halaman 220-233.

Cassidy, Simon. 2004. Learning Style: An Overview of theories, models, and measures. Educational Psychology. Vol. 24 (4): Hal. 419-444.

De Porter, Bobbi, dan Hernacki, Mike. 2002. Quantum Learning. Diterjemahkan oleh Alwiyah Adurrahman. Bandung: Kaifa PT Mizan Pustaka.

De Porter, Bobbi, Reardon Mark, Singer Sarah dan Nourie. 2000. Quantum Teaching. Editor, Hernacki, Mike. Diterjemahkan oleh Ary Nilandari. Bandung: Kaifa PT Mizan Pustaka.

Degeng, I.N.S \& Pali, Marthen. 2002. Model pembelajaran Berorientasi Pengembangan Kecerdasan Emosi di Sekolah Dasar: Faktor-faktor yang berpengaruh dalam rancangan pembelajaran. Laporan Riset Unggulan Terpadu VIII Bidang Dinamika Sosial, Ekonomi dan Budaya. Kementerian Riset dan Teknologi Republik Indonesia

Gilakjani, Abbas Pourhossein. 2012. Visual, Auditory, Kinaesthetic Learning Styles and Their Impacts on English Language Teaching. Journal of Studies in Education. Volume 2 (1): Halaman 104-113.

Lambas. 2008. Pengaruh Strategi Pembelajaran dan Gaya Belajar terhadap Hasil Belajar Matematika. Jurnal Teknologi Pendidikan. Yogyakarta: 10 (3), 149-160.

Nurlela, L. 2007. Pengaruh Model Pembelajaran, Gaya Belajar dan Kemampuan Membaca terhadap Hasil Belajar siswa SD di Kota Surabaya. Disertasi. Tidak diterbitkan. Malang: PPS Universitas Negeri Malang.

Parfin, Ronald L. 2009. Kiat Nyaman Mengajar di dalam Kelas Edisi ke-2 Jilid I. Jakarta: PT Indeks.

Rambe. A.A. 2011. Pengaruh Strategi Pembelajaran dan Gaya Belajar terhadap hasil belajar Bahasa Indonesia Siswa Kelas XI SMA Negeri 1 Kisaran. Jurnal Kultura. Asahan: Volume 12 (1): Halaman 1-19.

Suparman S. 2010. Gaya Mengajar yang Menyenangkan Siswa. Yogyakarta: Pinus Book.

White, April. 2004. Impact of Student Motivation on Teaching and Learning. The Agriculture Educational Magazine. Volume 76 (4): Halaman 14-16.

The 6Th International Conference on Educational Technology of Adi Buana, $9^{\text {th }}$ May 2015 


\section{BIODATA DIRI}

Abd. Ghofur, Lahir di Lamongan pada 26 Januari 1987. Lulus pendidikan Sarjana di Universitas Islam Darul Ulum Lamongan tahun 2009, kemudian tahun 2012 lulus Magister Teknologi Pembelajaran di Universitas PGRI Adi Buana Surabaya. Pada tahun 2013-sekarang melanjutkan program Doktor Teknologi Pembelajaran di Universitas Negeri Malang. Keseharian mengabdi menjadi Dosen Tetap di STKIP PGRI Lamongan dan aktif dalam berbagai forum ilmiah 